\title{
IMPLEMENTATION OF GOOD CORPORATE GOVERNANCE TO THE VALUE OF COOPERATIVE COMPANY
}

\author{
Rima Elya Dasuki ${ }^{1}$ and Ardiyani Lestari ${ }^{2}$ \\ ${ }^{1,2}$ Institut Manajemen Koperasi Indonesia (Indonesian Cooperative Management Institute) \\ ${ }^{1}$ rimadasuki@ikopin.ac.id
}

\begin{abstract}
Cooperatives are one of the institution that can carry out economic empowerment for the community. Cooperative business is directly related to the improve the business and welfare of members, so that with good supervision will have a high beneficial impact for members. Cooperative development policy should give priority to quality of cooperatives, to produces quality cooperatives required good supervision. The subject of the result are saving loan cooperatives in West JavaIndonesia . The type of research used in this study is descriptive research methods, namely research that uses primary and secondary data which is then processed and analyzed .Implementation of Good Corporate Governance encourages cooperative management in conducting savings and loan activities effectively and efficiently by taking into account the principles of cooperatives and prudential principles so that the cooperative assessment is transparent, accountable and responsive. Principles of Good Corporate Governance required by cooperatives to achieve business sustainability. Research Finding: Management of cooperatives can be done effectively and with the implementation of Good Corporate Governance the performance of cooperatives can be increased and improve service to the member. Cooperative development policy should give priority to quality of cooperatives, to produce quality cooperatives required good supervision.
\end{abstract}

Keyword: economic empowerment, cooperative, good corporate governance, value of firm

\section{Introduction}

The positive relationship between governance quality and firm performance is maintained and is stronger at low levels of concentrated ownership. More interestingly, we that the relationship between governance and firm performance is an increasing function of dispersed ownership and that the value addition of good governance is not necessarily maintained at high levels of ownership concentration (Abdallah \& Ismail, 2017).

Good Corporate Governance (GCG) is one of the key elements in increasing economic efficiency which includes a series of relationships between cooperative managers, cooperative managers, supervisors, capital owners and other stakeholders. Good Corporate Governance also provides a structure that facilitates a set of targets from a cooperative and as a means to determine work monitoring techniques. (Darmawati et al., 2004). There are two things that are emphasized in this concept. First, the right of shareholders to obtain the accurate information, and secondly, the obligation of the company to accurately and transparently disclose all information on company performance, ownership, and stakeholders.

Performance is a reflection of success in a business venture. Performance measurement is a measurement action carried out on various activities in the value chain that exist in the company , used as feedback that will provide information about the achievement of the implementation of a plan and the point where the company requires adjustments to planning and control activities.

The business of the Unit Coperative Banks can be bifurcated into two segments, micro finance function for 
their members and commercial bank function to non-members. Differentiating between the two areas is very crucial as they require different business, regulatory and governance strategies. Both the units may function independent of each other like different profit or business centers and transfer pricing mechanism may be used for funds transfer between them. The regulation could have differential treatment for these two different business areas and customize the guidelines accordingly. This would lead to a fine blend of social and business entrepreneurships (Asher, 2007).

The findings revealed a significant and positive relationship between monitoring rights and social performance. Besides, there was also a significant and positive relationship between innovation and social performance. However, the relationship between ratification of management decisions and social performance, and policy compliance and social performance was not statistically significant. (Kyazze, Nkote, \& Wakaisuka-Isingoma, 2017). Many parties have begun to think that the application of corporate governance is a necessity in the business world as a barometer of accountability of a company (Totok Dewayanto, 2010).

Two Thousands and fifteen (2015) was marked as the beginning of a change in development strategy and guidance cooperatives, because since then the direction of cooperative development policies has mainstreamed into quality rather than cooperative quantity. To produce quality cooperatives, it is believed that supervision of cooperatives is needed (Dasuki, 2018b).

\section{Theoretical Framework}

\subsection{Good Corporate Governance}

The World Bank defines GCG as a regulation for business organizations that regulates the behavior of the management of the company and describes the duties and authorities as well as accountability to those who have authority Due to the checks, crisis which happen in a business lately, realizes the steak holders to run the business more sporty, transparent, honest, accountable in management and trust in managing the organization, institution, wealth or other resources to reach the goals. To reach these goals, many theories and policy appear such as the management system and another concept such as good. (Siboro, 2007). The quality of corporate governance is a condition needed to guarantee and maintain stakeholder trust (Fathi, 2013). According to National Committee on Governance (2006) GCG principles include transparency, accountability (accountability), responsibility (responsibility), independency (independence), and fairness (equality and fairness). According to National Committee on Governance (2006) Good Corporate Governance principles are needed in order to achieve the sustainability of the company's.

The corporate governance of a cooperative consists of designing mechanisms and setting up institutions that encourage workers to define a goal that maximizes workers wealth or welfare (first level of governance) and, further- more, induces managers to internalize such goals (second level of governance). (Surroca, García-Cestona, \& Santamaria, 2006).

There are five principles of good corporate governance (GCG) according to the National Committee on Governance (KNKG); transparency, accountability, independence, responsibility and fairness.

\section{Transparency}

One of the good corporate governance (GCG) principle forms is to open the public information access based on the transparency corridor and information transparency. One of those information is the accounting report. The accounting report which is 
made must have significance meaning, or there isn't any hidden information or disclosure. (Siboro, 2007)

2. Accountability

That is the implementation and accountability of the organization management (company) so that the management of the organization runs effectively. An organization is accountable, if the organizational elements are able to function optimally and are able to account for their duties and functions effectively. This condition can only occur if, there are clarity of rules, tasks, functions, work mechanism, job description for each organ of the organization. (Prijambodo, 2012).

3. Independence

That is a state of the organization (company) managed professionally, without conflict of interest/influence from any party that is not in accordance with applicable laws and regulations. In this principle of independence there is no domination of one party to another, and the organization cannot be intervened by other parties.

4. Responsibility

Implementation of the principle of accountability is characterized by the success of the organization in fulfilling compliance with the applicable laws and regulations, internal regulations of the organization (company).

5. Fairness

That is justice and equality in fulfilling the rights of equality and fairness can be defined as fair and equal treatment in fulfilling the rights of stakeholders that arise based on the agreement and the applicable laws and regulations. Fairness also includes the clarification of the rights of investors, the legal system and enforcement of regulations that protect the rights of investors, especially minority shareholders of various forms of fraud.
The objectives of the implementation of Good Corporate Governance according to the National Governance Policy Committee are as follows:

1. Encouraging the achievement of corporate sustainability through management based on the principles of transparency, accountability, responsibility for independence and equality and fairness.

2. Encouraging the empowerment of functions and independence of each company organ, namely the Board of Commissioners, Directors and the General Meeting of Shareholders.

3. Encouraging shareholders, members of the Board of Commissioners, and members of the Board of Directors to make and carry out their actions based on high moral values and compliance with laws and regulations.

4. Encouraging the emergence of corporate social awareness and responsibility towards the community and environmental sustainability especially around the company.

5. Optimizing company value for shareholders while paying close attention to other stakeholders.

6. Increasing the competitiveness of companies nationally and internationally, so as to be able to increase market confidence that can encourage the flow of investment and sustainable national economic growth.

In general, companies that have succeeded in implementing Good Corporate Governance use the following phases: Good Corporate Governance and implementation in Indonesia (Kaihatu, 2006)

\section{Preparation}

This stage consists of three main steps, namely 1) building awareness, 2) Good Corporate Governance assessment, 3) Good Corporate Governance manual building. Awareness building is the initial step of socialization to build awareness about the importance of Good Corporate Governance and mutual 
commitment in its implementation. This effort can be done by asking for help from independent experts from outside the company. Forms of activities can be carried out through seminars, workshops and group discussions (Daniri 2005).

Good Corporate Governance assessment is an effort to measure the condition of the company in the implementation of current Good Corporate Governance. This step is necessary to ensure the starting point or level of implementation of Good Corporate Governance and to identify appropriate steps to prepare infrastructure and corporate structures that are conducive to the implementation of good corporate governance effectively.

Based on the results of mapping the level of readiness of the company and efforts to identify priority applications, the preparation of manuals or guidelines for implementing Good Corporate Governance can be prepared. Manual preparation can be done with the help of independent experts from outside the company. This manual can be distinguished between manuals for company organs and manuals for all company members, covering various aspects such as:

a. Good Corporate Governance policies of the company,

b. Good Corporate Governance guidelines for corporate organs,

c. Behavioral guidelines,

d. Audit committee charter,

e. Disclosure policy and transparency,

f. Risk management policies and framework, and

g. Implementation roadmap.

\section{Implementation}

After the company has a manual Good Corporate Governance, the next step is to start implementation in the company. This stage consists of three main steps, namely (1). Socialization, implementation, (3) internalization. Socialization is needed to introduce to all companies various aspects related to the implementation of Good Corporate Governance, especially regarding guidelines for the implementation of Good Corporate Governance. Socialization efforts need to be carried out with a special team formed for that, directly under the supervision of the President Director or one of the Directors appointed as GC champions in the company (Daniri 2005). Implementation is an activity carried out in line with existing Good Corporate Governance guidelines, based on the roadmap prepared. Implementation must be a top down approach involving the Board of Commissioners and Directors of the company. Implementation should also include change management efforts to guard the process of change caused by the implementation of Good Corporate Governance.

Internalization is a long-term stage in implementation. Internalization includes efforts to introduce Good Corporate Governance in the entire business process of the company through various operating procedures (such as procurement procedures, etc.), work systems, and various company regulations. With this effort, it can be ascertained that the implementation of Good Corporate Governance is not merely a surface or just a superficial compliance, but is truly reflected in all company activities.

\section{Evaluation}

The evaluation is a stage that needs to be carried out regularly to measure the extent to which the effectiveness of the implementation of Good Corporate Governance has been carried out by asking independent parties to carry out implementation audits and scoring on existing Good Corporate Governance practices. There are many consulting companies that can provide such audit services, and in Indonesia there are several companies that do scoring. Evaluations in the form of assessments, audits or scoring can also be carried out man datively. Evaluation can help 
companies remapping the conditions and situations and company achievements in implementing Good Corporate Governance so that they can improvements based on the recommendations given.

Cooperatives must be managed properly so that they can improve their performance on an ongoing basis. Therefore the State Ministry of Cooperatives and Small and Medium Enterprises is intensively socializing Good Corporate Governance in cooperatives to the public so that the management of cooperatives can be carried out effectively and efficiently.

\subsection{Value of Firm/Cooperative Value}

The purpose of cooperatives is member welfare, namely meeting the interests of its members and the community in order to improve the welfare of life. To achieve this, even though cooperatives are not profit-oriented capital associations, capital is an important factor to achieve this goal in addition to other resource factors (Heiko, 2007)

Although it is entirely the responsibility of the directors to prepare financial statements, undertake external audit can significantly influence the amount of information disclosed. Audit function has a key role in the control of the management of companies where the owners do not ensure stewardship. This relationship is consistent with agency theory. Large audit firms have a strong incentive to maintain their independence and to impose more stringent disclosure standards because they have more to lose from deterioration of their reputation.(Jouini, 2013)

Shareholder and manager are ostensibly on the same side yet can be striving for markedly different goals. Self-interest is a powerful motivator and it is no different here. The shareholder injects capital into the company and naturally seeks a decent return on this investment. On the other hand, the executive will be driven by desires of promotion, higher earnings and increased power and influence.(Group \& Limited, 2004).

The benefits of cooperatives which are reflected in their goals are to improve the welfare of members both in economic and social levels (Dasuki, 2018a).

Cooperative return are also one of the important elements in improving the welfare of members. usually accumulates from calculating services to cooperatives (Dasuki, 2018a).

Yuyun Wirasasmita (2005) explained that the measure of the success of cooperative efforts is not merely a measure of the efficiency of cooperatives as a company, but with a measure of efficiency in order to increase the welfare of members with their social impacts.

Besides return cooperative, there are still many other benefits provided by the cooperative to its members, especially in the financial sector. Basically the benefits that members get from cooperatives are a price benefit. (Dasuki, 2018a).

Value of firm can be seen from the position of wealth, liabilities and equity of the cooperative and its ratio of measurement ratios related to profitability.

The performance analysis of cooperatives can describe cooperative business performance both related to quantitative and qualitative aspects, where the results of the analysis can describe the value of cooperative companies. The higher the value of the cooperative company, the more independent the cooperative will be, which in turn will provide direct benefits to members. When members get direct benefits, it is expected that member participation will increase. This will have an impact on improving business performance will increase the cooperative value of the company and the welfare of its members. The association 
of cooperative valuation of cooperative company values can be illustrated as follows: Value measurement is done using the Return On Asset approach, where the variable variance can be described as follows.

The type and level of participation may obviously differ depending on the kind of service or the environment in which the service is delivered, and this then affects the level of satisfaction perceived by the customer. Customer participation in the delivery process may also be perceived in different ways by the customers themselves. It can actually lower their perception of the quality of the service (consider, for instance, the interaction of customers unfamiliar with vending machines), and so have a negative effect on their level of satisfaction. In other cases it can reduce the amount of time required to deliver the service, or satisfy customers who like to be independent and in control of the situation. (Ippolito, 2009).

\subsubsection{Total assets}

Total assets are the total assets used by companies / cooperatives in one book year. When the main owner has effective control over the firm (i.e., absolute control or less than absolute control but without the control of a second significant shareholder), the relation between ownership concentration and firm value is U-shaped.(Lozano, Martínez, \& Pindado, 2016).

\section{Current asset}

Current assets are assets that are expected to be realized within one year or in the normal operational cycle of the company, which are longer current assets include: cash and banks, securities, short-term deposits, notes receivable that are due within one year, trade accounts receivable, other accounts receivable, inventories, down payment for the purchase of current assets, payment of initial tax, prepaid expenses (insurance premiums, interest on stationery and office supplies

\subsubsection{Investment assets}

Investment is an asset used by companies for wealth growth through distribution of investment returns (such as interest, royalties, dividends and rent). Investments that can be immediately disbursed and intended to be owned a year or less are included in the group of current assets. While investments other than current investments are classified as long-term investments. Property investment is investment in land or buildings that are not used or operated by companies that invest. Trade invasion is an investment intended to facilitate or trade relations.

\section{Fixed Asset}

Fixed assets are tangible assets acquired in the form of ready-to-use or with earlier construction that are used in company operations not intended to be sold in the context of the company's normal activities and have benefits of more than one year.

Fixed assets include assets that cannot be depreciated and depreciated. Linking is the systematic allocation of the amount that can be depreciated from an asset for the duration of its usefulness.

\section{Intangible Assets (Asset Intangibles)} Intangible assets are non-form and noncurrent assets that provide economic and legal rights to their owners and are not included separately in other asset classifications in financial statements. Intangible assets can be in the form of: copyright, franchise, goodwill trademark.

\subsubsection{Loan Capital}

Loan capital or liabilities are current corporate debts arising from past events, their completion is expected to result in an outflow of company resources containing economic benefits.

\section{Short-term Debt}

Short-term debt is an obligation that will be repaid in accordance with the creditor's request or that will be repaid in one year. 
Short-term liabilities include bank loans and other loans, part of long-term liabilities that will mature within one year from the balance sheet date, purchase assets of fixed assets, bank loans and other types of debt that must be repaid within one year, allowance tax liability, dividend debt, deferred income and advances from customers.

\section{Long-term Liabilities (Long-term Debt)}

Long-term debt is an obligation that will not be due within one year. However, if the liability falls short, the obligation will be classified as a short-term liability. Its long-term liabilities consist of mortgage debt and bonds payable.

\subsubsection{Equity}

Equity or own capital is part of the owner's rights in acompany or coperative, namely the difference between assets and liabilities that exist.

a. Principal Deposits

Funds are deposited by members of the cooperative when they first enter the cooperative.

b. Mandatory savings

Funds are periodically deposited by members of cooperatives with a certain amount agreed upon at a cooperative member meeting.

c. Grants

Is funds provided by other parties with the aim of strengthening the capital of cooperatives.

d. Reserve

Funds that are intended for strengthening the capital of cooperatives that come from a portion of the profits / cooperatives.

\subsubsection{Return On Asset (ROA)}

Return on assets is a ratio that measures the ability of assets to generate profits. Or as the effectiveness of asset use. ROA is used to measure the ability of a business organization to generate profits from its operational activities by utilizing assets owned, by knowing this ratio will be known whether the company's assets have been used efficiently for the company's operations. To analyze the financial performance of the cooperative, ROA is used as a measurement tool where the remaining results of the business obtained are compared with the total assets of the cooperative in the year. (Pradnyaswari \& Putri, 2016)

\section{Return of Cooperative}

The net cooperative income is the income of cooperatives obtained in one financial year minus depreciation costs and other obligations including taxes in the relevant financial year.

The remainder of the proceeds after deducting the reserve fund is distributed to members in proportion to the business services provided by each member with the cooperative and used for cooperative education and other requirements of the cooperative in accordance with the decision of the meeting of members.

\section{Methodology}

3.1. Scope of Research

Twenty Two Saving and Credit Sharia Cooperatives in West Java regularly submit reports to the Department of Cooperatives in West Java for at least 3 consecutive years

\subsection{Research Methods Used}

The type of research used in this study is descriptive research methods, namely research that uses primary and secondary data which is then processed and analyzed to be taken as a conclusion

\subsection{Data Types Used}

The type of data used according to how to obtain it in this study are:

a. Primary Data

b. Secondary Data

\subsection{Sources and methods of determining data \\ Data source}

1. Respondents

2. Informants 
3. Institutions are secondary data sources that are relevant to the case under study.

4. Records or documents.

\subsection{Data collection technique}

The data used in this study are primary data and secondary data. Primary data is data obtained directly from the subject and object of research. Primary data is obtained from the following results:

1. Observation.

2. Interview.

3. Questionnaire.

\section{Library Studies}

Secondary data is data collected by other parties. Secondary data obtained from:

1. Documentation studies

2. Literature study, namely the technique of collecting data obtained by reading and studying the literature, lecture notes and other sources relevant to the problem under study.

\subsection{Variable Operationalization}

Table 1. Variable Operationalization

\begin{tabular}{cll}
\multicolumn{3}{c}{ VARIABLES 1: Good Corporate Governance } \\
\hline NO & \multicolumn{1}{c}{ VARIABLES } & \multicolumn{1}{c}{ INDICATOR } \\
\hline 1 & Transparency & Information disclosure \\
\hline 2 & Accountability & $\begin{array}{l}\text { Clarity of Functions, Rules, Tasks } \\
\text { Job Description for each organ }\end{array}$ \\
\hline 3 & Responsibility & $\begin{array}{l}\text { Compliance with applicable laws and regulations } \\
\text { Implementation of the principle of accountability }\end{array}$ \\
& &
\end{tabular}

Source: Data Processing

\begin{tabular}{clll} 
& \multicolumn{2}{c}{ Table 2. Variables 2 Value Of Firm } \\
\hline No. & \multicolumn{1}{c}{ Sub Variable } & & Indicator \\
\hline 1 & Total Assets & $\begin{array}{l}\text { Current asset } \\
\text { Fixed assets }\end{array}$ \\
\hline 2 & Loan Capital & $\begin{array}{l}\text { Long-term debt } \\
\text { Short-term Debt }\end{array}$ \\
\hline 3 & Equity & Basic deposit \\
& & Mandatory Deposits \\
\hline 4 & Return On Asset & SHU \\
& & Total Assets \\
\hline
\end{tabular}

Source: Data Processing

\section{Result and Discussion}

4.1. Implementation of Good Corporate Governance

4.1.1. Application of 5 aspects of Good Corporate Governance in the Office of Cooperatives and Small Business of West Java Province

The concept of Good Corporate Governance is applied in managing cooperatives, which have been pioneered and applied by cooperatives in developed countries. Good Corporate Governance is defined as good organizational governance.The implementation of the Good Corporate

Governance concept is important to be carried out by cooperatives considering Good Corporate Governance because:

1. It is a structure that regulates a harmonious relationship pattern between the management and other members and stakeholder. 
2. A system of management checking in the organization.

3. A transparent process for determining organizational goals, achieving performance and measuring success.

According to the National Governance Policy Committee, there are five principles in GCG, the 5 principles are right to be applied in cooperatives. The concept of GCG is very relevant to the concept of development of cooperatives that lead cooperatives that carry out modern management, because modern cooperatives must have good governance principles in management. The 5 GCG principles include (1) Accountability, (2) Accountability, (3) Transparency, (4) Fairness, (5) Independence.

1. Accountability

a. Form of responsibility for the implementation of functions and tasks according to the authority possessed by the cooperative organ.

b. Managers, supervisors, supervisors, managers, members, and cofinancers, must be committed to the development of cooperatives.

c. Accountability for planning, implementation, supervision of all cooperative activities must be in line with the vision, mission, objectives of the cooperative.

d. Accountability for achieving continuous, professional performance in carrying out their duties.

e. Clarity of functions so that organ accountability in the cooperative is carried out effectively.

The Office of Cooperatives and Small Business of West Java Province has implemented this principle well because of the clarity of rules, duties, functions, work mechanisms, job descriptions of each organ that has been carried out optimally. This can be seen in each organ or section must prepare an accountability report.
2. Responsibility

a. Responsibility to the community and the environment, for the sustainability of a long-term joint venture.

b. The responsibility for regulations and laws, which must be obedient, because cooperatives are part of the community.

c. The same responsibility for all organs of cooperatives, in accordance with their authority.

d. The implementation of this principle has been very good because each official has complied with the applicable laws and regulations as well as internal regulations. The regulations are the Civil Service Regulations and the Office Regulations themselves.

3. Transparency

a. Information on cooperative performance, namely transparency in carrying out cooperative activities, timeliness, decision making, supervision, fairness, standardization, cost efficiency.

b. Objectivity in running a business, accessing information, relevant to the interests of members.

Transparency applied by the West Java Provincial Cooperative and Small Business Office is quite good. This is because when making decisions not only by the Head of Service, but also involving other employees such as Head of Division. This transparency is also applied to the financial statements of activities or projects. This report will then be examined by the inspectorate every year

4. Fairness

a. Protect the interests of minority stakeholders from fraud.

b. Stakeholder can be protected from abuse of authority of cooperative managers.

c. Avoid manipulation, so that they always pay attention to the principle of togetherness and equality. 
d. Fair and equal treatment has been applied to the cooperative service to its employees. Every employee has the same right to get a position, as long as he fulfills the requirements such as according to rank and class, education level, is active in various activities and gets recommendations from superiors.

5. Independence of Independence

a. Free from external pressure, which is not in accordance with the cooperative mechanism.

b. The cooperative decides, must be the confidence of the cooperative stakeholders, not the influence from outside the cooperative.

c. Free from outside domination, must be independent, must not accept intervention from outside the West Java Provincial Cooperative and Small Business Office has been professionally managed without any outside interests. This is because the purpose of the service is not profit oriented but excellent service.

Implementation of Good Corporate Governance in cooperatives must pay attention to guidelines related to:

1. The principle of accountability.

2. The principle of accountability.

3. The principle of transparency.

4. The implementation of the principle of fairness.

5. The principle of independence.

Practical Reference to the Accountability Principle

1. Understand well, in depth the vision and mission, by describing it into cooperative targets.

2. Understand specifically the tasks, responsibilities, so that they do not overlap.

3. Understanding the decision-making process carefully, because in cooperatives must pay close attention to the aspirations of members, in the meeting of members.

4. Understanding the check and balance process, namely the supervisory function of carrying out duties, regarding the role of members, administrators, supervisors, supervisors.

5. Understand the operational performance appraisal system accurately, achievement compared to targets, and benefits for the purpose of the cooperative.

6. Understand the stages of assessment by using (1) what will be evaluated, (2) evaluation design, (3) data collection, (4) data analysis, (5) assessment reporting, (6) follow-up assessment results.

Practical Reference to the Responsibility Principle

1. Understand all applicable regulations because regulations are essential in cooperative governance.

2. Understanding the values adopted, namely habits that are run by all components of the cooperative, based on kinship.

3. Togetherness in the spirit of mutual cooperation in cooperatives must be developed, so that in addition to prosperity also build a conducive atmosphere.

4. The decision making process must be monitored and criticized by member meetings.

5. There are stages in making decisions that can be applied by cooperatives:

(A) types of decisions, consisting of 2 types of decisions, namely (a) structured decisions (decisions that must have clear rules \& can be delegated), (b) unstructured decisions (cannot be delegated \& must have strong intuition).

(B) Decision making skills, must have intelligence, capacity, capability, sense of responsibility, of these values (1) type of dependency (lack of assertiveness, weak position, problem not mastered, so need help), (2) type of savings ( lots of ideas, delivered at the right time), (3) type of marketing (publish ideas to others, so sympathy), (4) type of 
productive (have the ability, knowledge, competence, initiative, creative, working together).

Practical Reference to the Principle of Transparency

1. Appointment manager's decision, based on member meetings.

2. The right of members to obtain open financial information.

3. Transparency to important transactions.

4. The supervisor has the authority to examine important records, but still must maintain confidentiality.

5. Ensure disclosure of every financial and non-financial problem.

Reference to Implementation of the Fairness Principle

1. Managers must be committed to regulations.

2. Equitable, fair treatment to all stakeholders.

3. Team development works, is compact in governance.

Reference to Implementation of the Principle of Independence

Table 3: Accountability

\begin{tabular}{|c|c|c|c|c|}
\hline $\mathrm{NO}$ & Aspect & Score & Percentage & Criterion \\
\hline \multirow{9}{*}{1} & \multicolumn{3}{|l|}{ ACCOUNTABILITY } & \\
\hline & a. The cooperative has been running in & 161 & $82,56 \%$ & \multirow[t]{2}{*}{ Good } \\
\hline & 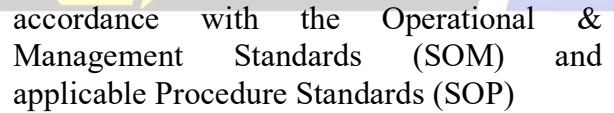 & & & \\
\hline & \multirow{2}{*}{$\begin{array}{l}\text { b. Each division / part of the cooperative is } \\
\text { filled by people who are competent in their } \\
\text { field }\end{array}$} & 172 & $88,21 \%$ & Very Good \\
\hline & & & & \multirow{3}{*}{ Very Good } \\
\hline & $\begin{array}{l}\text { c. There is no duplicate position or vacant } \\
\text { position the cooperative }\end{array}$ & 151 & $77,44 \%$ & \\
\hline & $\begin{array}{l}\text { d. The cooperative has used special software } \\
\text { to make its performance effective }\end{array}$ & 179 & 91,79 & \\
\hline & \multirow{2}{*}{ Total } & 663 & & \multirow{2}{*}{ Very Good } \\
\hline & & $85 \%$ & & \\
\hline
\end{tabular}

Source: data processing

From table 3 above, it can be seen that the average respondent's answer is Very Good which is equal to $85 \%$ of the overall statement. The indicator with the
1. Every decision must be free from interests that harm the cooperative.

2. Free from conflicts of interest, influence, pressure from anywhere.

3. An objective decision-making process, so as to present the interests of the members.

Good Corporate Governance Steps in Cooperatives

1. Aligning the goals of cooperatives with the spirit of cooperatives, that the goals of cooperatives really are for the welfare of members.

2. Make continuous improvements in a comprehensive, professional, effective, efficient manner.

3. Improving the internal conditions of cooperatives.

\subsubsection{Implementation of Good Corporate Governance in Sharia Savings and Credit Cooperatives.}

The following are the results of the Good Corporate assessment of sharia saving and credit cooperative in west Java: highest statement value is found in item 4 , the cooperative has used special software to make its performance effective, the percentage of this indicator 
is $91.79 \%$. While the lowest percentage is in item 3, that is, there are no double position in cooperatives with a percentage of $83.6 \%$. It can be concluded that the respondents, namely the administrators or employees of more cooperatives, agreed that the cooperative had used special software to increase its performance. According to them, cooperatives usually buy software at companies or services that sell it. And the respondents also disagreed with the statement that there were no concurrent positions or vacant positions in the cooperative. Because according to the respondents this generally happens because cooperatives have not been able to recruit new employees because of the lack of a budget to hire these employees, there are no people who are competent in that field, and so on.

Table 4 : Responsibility

\begin{tabular}{|c|c|c|c|c|}
\hline $\mathrm{NO}$ & Aspect & Score & $\%$ & Criterion \\
\hline 2 & \multicolumn{4}{|l|}{ RESPONSIBILITY } \\
\hline & $\begin{array}{l}\text { a. The cooperative has good security for all } \\
\text { important documents }\end{array}$ & 147 & $75,38 \%$ & Good \\
\hline & $\begin{array}{l}\text { b. Cooperatives routinely hold RATs every } \\
\text { year }\end{array}$ & 169 & $86,67 \%$ & Very good \\
\hline & c. Cooperatives have legal / legal entities & 157 & $80,51 \%$ & Good \\
\hline & $\begin{array}{l}\text { d. The cooperative adheres to every } \\
\text { commitment both with members and } \\
\text { other parties }\end{array}$ & 152 & $77,95 \%$ & Good \\
\hline & \multirow{2}{*}{ Total } & 625 & & \multirow{2}{*}{ Good } \\
\hline & & $80,13 \%$ & & \\
\hline
\end{tabular}

Source: Data processing

From table 4 above, it can be seen that the average respondent's answer is Good which is equal to $80.13 \%$. The indicator with the highest statement value is found in item 2, that is, the Cooperative routinely organizes Member Annual Meeting every year, the percentage of this indicator is $86.67 \%$. While the lowest percentage is in item 1 , the cooperative has good security for all important documents with a percentage of $75.38 \%$. It can be concluded that the respondents, the administrators or employees of more cooperatives, agreed that cooperatives routinely hold Member Annual
Meeting every year. According to them, the Member Annual Meeting is always done considering that Member Annual Meeting is their responsibility for what has been done for one year. Member Annual Meeting also describes plans that will be carried out by the cooperative in the future, usually for the next one year. Respondents disagree on the statement that the cooperative has good security. According to them, most cooperatives do not have special safes so that cooperatives only store the documents in the available cabinets or leave the documents to the parties.

Table 5.Transparancy

\begin{tabular}{lllll}
\hline No & Aspect & Score & $\%$ & Criterion \\
\hline $3 \quad$ TRANSPARANCY & & & \\
\hline & $\begin{array}{l}\text { a. Cooperatives present financial statements } \\
\text { such as cash, income statements, balance } \\
\text { sheets, transparently. }\end{array}$ & & $96,9 \%$ & Very good \\
& $\begin{array}{l}\text { b. } \\
\quad \begin{array}{l}\text { The Cooperative announces cooperation } \\
\text { with other parties }\end{array}\end{array}$ & 163 & $83,6 \%$ & Good \\
c. $\begin{array}{l}\text { Cooperatives convey information on } \\
\text { service products clearly }\end{array}$ & 179 & $91,79 \%$ & Very Good \\
\hline
\end{tabular}




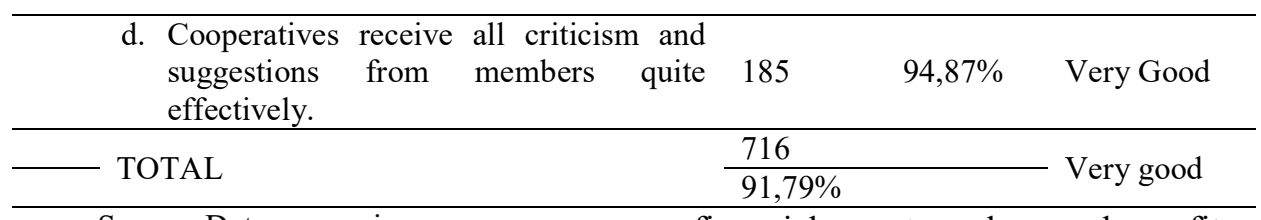

Source: Data processing

From table 5 above, it can be seen that the average respondent's answer is Very Good at $91.79 \%$. The indicator with the highest statement value is found in item 1 , that is, the Cooperative presents financial reports such as cash, loss reports, balance sheets, transparently, the percentage of this indicator is $96.9 \%$.

While the lowest percentage is in item 2, the cooperative announces cooperation with other parties with a percentage of $83.6 \%$. It can be concluded that the respondents, the administrators or employees of more cooperatives who agree that the cooperative has presented financial reports such as cash, profit and loss statement reports, balance sheets, in a transparent manner. These financial statements are usually listed on the last page in the Member Annual Meeting book. And the respondents also disagreed with the statement that the cooperative announced cooperation with other parties. Because according to the respondents the collaboration is generally only known by the management or employees of the cooperative, considering that members who tend to only use the facilities, do not know how to get it.

Table 6: Independency

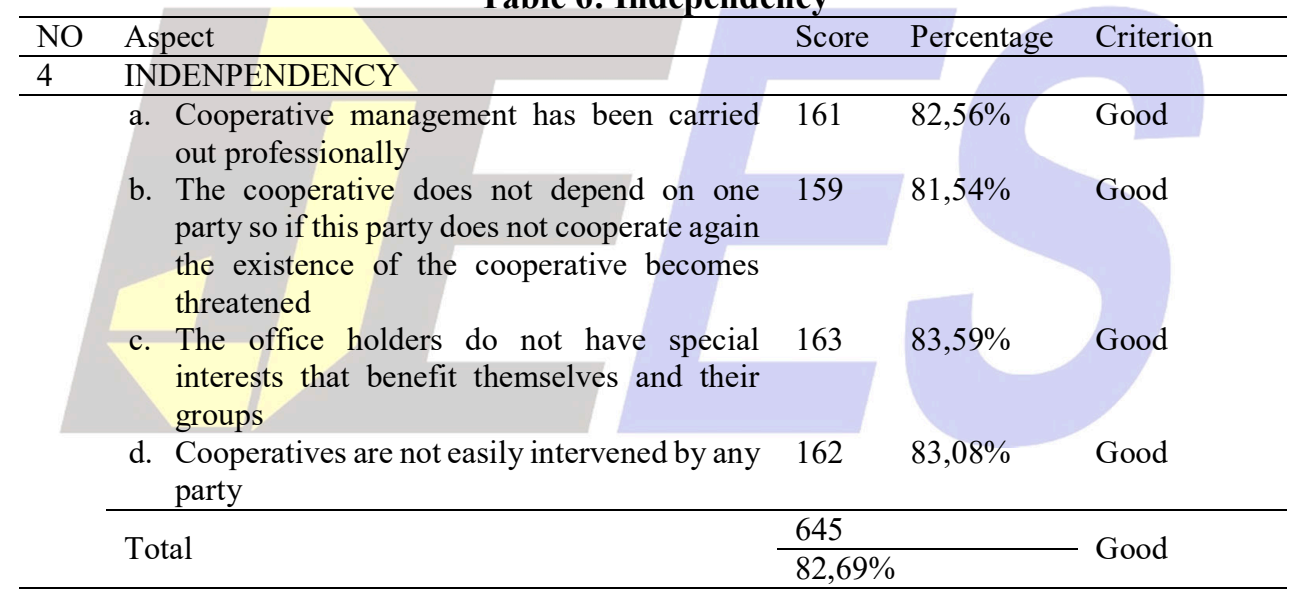

Source: Data Processing

From table 6 above, it can be seen that the average respondent's answer is Good which is equal to $82.69 \%$. The indicator with the highest statement value is found in item 3 , that is, office holders do not have special interests that benefit themselves or their groups, the percentage of this indicator is $83.59 \%$. While the lowest percentage is in item 2, that is, cooperatives are not dependent on one party so that if this party does not cooperate again the existence of the cooperative becomes threatened, with a percentage of $81.54 \%$. It can be concluded that the respondents, namely the holders of office do not have special interests that benefit

themselves and their groups. According to them, the position holders have worked in accordance with the provisions that exist so that they can avoid fraud. And the respondents also disagreed with the statement that the cooperative did not 
depend on one party so that if this party did not cooperate again the existence of the cooperative would be threatened. Because according to the respondents, this generally happens because cooperatives have not been able to

Table 7: Fairness

\begin{tabular}{lllll}
\hline NO & Aspect & Score & Percentage & Criterion \\
\hline 5 & FAIRNESS & & & \\
\hline & $\begin{array}{l}\text { a. Members are treated equally or not } 172 \\
\text { discriminated }\end{array}$ & $87,69 \%$ & Very good \\
b. Members have received quality service & 148 & $75,89 \%$ & Good \\
c. The supervisor has carried out the task \\
$\begin{array}{l}\text { properly so that the cooperative is } \\
\text { protected from fraud }\end{array}$
\end{tabular}

Source: Data Processing

From table 7 above, it can be seen that the average respondent's answer is Good which is equal to $77.82 \%$. The indicator with the highest statement value is found in item 1 , that is, members are treated equally or not discriminated, the percentage of this indicator is $87.69 \%$. While the lowest percentage is in item 3, the supervisor has done the task correctly so that the cooperative is protected from fraud, with a percentage of $67.69 \%$. It can be concluded that the respondents agreed more with the statement that members were treated equally or not discriminated. independently and finance the businesses so that cooperatives need or much work together with the banking sector or another financial institution.

\subsection{Cooperatives Financial Performance (Value of Firm)}

Table 8: Cooperatives Financial Performance

\begin{tabular}{|c|c|c|c|c|c|c|c|}
\hline No & Cooperative & ASSET & DEBTS & EKUITY & RETURN & $\begin{array}{l}\text { RETURN } \\
\text { ON } \\
\text { ASSET }\end{array}$ & $\begin{array}{l}\text { RETURN } \\
\text { ON } \\
\text { EQUITY }\end{array}$ \\
\hline 1 & $\begin{array}{l}\text { KSP Kristina } \\
\text { Jaya }\end{array}$ & 3.153 .901 .278 & 1.702 .873 .566 & 1.451 .027 .712 & 104.351 .360 & 0,03309 & 0,07192 \\
\hline 2 & $\begin{array}{l}\text { KPPS BMT } \\
\text { Mustama }\end{array}$ & 5.621 .227 .693 & 39.507 .500 & 542.046 .572 & 65.066 .559 & 0,01158 & 0,12004 \\
\hline 3 & $\begin{array}{l}\text { KPPS } \\
\text { Mardotilah } \\
\text { Sumedang } \\
\end{array}$ & 19.646 .675 .730 & 9.189 .178 .551 & 2.863.339.879 & 117.764 .048 & 0,00599 & 0,04113 \\
\hline 4 & KBMT Itqan & 37.003 .754 .439 & 24.288 .063 .975 & 23.288 .063 .975 & 446.818 .165 & 0,01207 & 0,01919 \\
\hline 5 & $\begin{array}{l}\text { KSPPS BMT } \\
\text { Assalam }\end{array}$ & 13.784 .421 .486 & 6.654 .509 .515 & 1.690 .076 .746 & 37.156 .723 & 0,00270 & 0,02199 \\
\hline
\end{tabular}


Journal of Economic Empowerment Strategy (JEES) Vol. 02, Number 01, February 2019

\begin{tabular}{|c|c|c|c|c|c|c|c|}
\hline No & Cooperative & ASSET & DEBTS & EKUITY & RETURN & $\begin{array}{l}\text { RETURN } \\
\text { ON } \\
\text { ASSET } \\
\end{array}$ & $\begin{array}{l}\text { RETURN } \\
\text { ON } \\
\text { EQUITY }\end{array}$ \\
\hline 6 & $\begin{array}{l}\text { KSPPS Al } \\
\text { Amanah }\end{array}$ & 42.367 .614 .728 & 37.181 .630 .357 & 4.975 .243 .118 & 210.741 .303 & 0,00497 & 0,04236 \\
\hline 7 & $\begin{array}{l}\text { KSPPS Quantum } \\
\text { Viss }\end{array}$ & 2.084 .612 .123 & 1.802 .000 .000 & 132.680 .401 & - & 0,00000 & 0,00000 \\
\hline 8 & $\begin{array}{l}\text { KSPPS Dana } \\
\text { Ukhuwah }\end{array}$ & 19.768 .867 .217 & 148.985 .000 & 1.835 .726 .351 & 279.669 .052 & 0,01415 & 0,15235 \\
\hline 9 & $\begin{array}{l}\text { KSPPS BMT } \\
\text { Tazkiah }\end{array}$ & 819.330 .068 & - & 60.166 .000 & 59.740 .579 & 0,07291 & 0,99293 \\
\hline 10 & $\begin{array}{l}\text { BMT Dana } \\
\text { Ukhuwah }\end{array}$ & 2.099 .367 .041 & 148.985 .000 & 1.950 .382 .041 & 292.878 .753 & 0,13951 & 0,15016 \\
\hline 11 & $\begin{array}{l}\text { KSPPS } \\
\text { Ibadurahman }\end{array}$ & 35.778 .081 .400 & 20.021 .006 .218 & 15.757 .076 .182 & 226.461 .977 & 0,00633 & 0,01437 \\
\hline 12 & $\begin{array}{l}\text { KBMT } \\
\text { Mardotilah } \\
\text { Krawang } \\
\end{array}$ & 1.747 .756 .493 & - & 1.416 .684 .447 & 99.250 .000 & 0,05679 & 0,07006 \\
\hline 13 & $\begin{array}{l}\text { Kop Insan } \\
\text { Mandiri }\end{array}$ & 350.000 .000 & 300.000 .000 & 50.000 .000 & 22.775 .000 & 0,06507 & 0,45550 \\
\hline 14 & $\begin{array}{l}\text { Kopontren Darut } \\
\text { Tauhid }\end{array}$ & 49.739 .442 .729 & 3.563 .141 .123 & 6.710 .683 .475 & 1.606 .172 .006 & 0,03229 & 0,23935 \\
\hline 15 & $\begin{array}{l}\text { Kopontren Al } \\
\text { Ihlas }\end{array}$ & 26.402 .142 .544 & 1.642 .091 .458 & 1.273 .507 .981 & - & 0,00000 & 0,00000 \\
\hline 16 & Kop Baitul Ihtyar & 48.858 .878 .775 & 40.956 .702 .220 & 7.902 .175 .545 & 838.517 .305 & 0,01716 & 0,10611 \\
\hline 17 & Kop Musyikat & 2.844 .603 .901 & 250.000 .000 & 1.135 .292 .056 & 135.050 .920 & 0,04748 & 0,11896 \\
\hline 18 & $\begin{array}{l}\text { KSPPS BMT } \\
\text { Barrah }\end{array}$ & 36.864 .013 .391 & 2.315 .339 .730 & 7.897 .863 .073 & 608.823 .229 & 0,01652 & 0,07709 \\
\hline 19 & $\begin{array}{l}\text { KSPPS Artha } \\
\text { Prima }\end{array}$ & 1.102 .413 .145 & 6.518 .920 .246 & 4.908 .808 .164 & 1.102 .413 .145 & 1,00000 & 0,22458 \\
\hline 20 & $\begin{array}{l}\text { BMT Bina } \\
\text { Keluarga }\end{array}$ & 1.104 .662 .813 & 883.255 .068 & 199.640 .851 & 16.766 .894 & 0,01518 & 0,08399 \\
\hline 21 & BMT Sanama & 9.975 .355 .451 & - & 1.815 .077 .918 & 116.202 .881 & 0,01165 & 0,06402 \\
\hline 22 & $\begin{array}{l}\text { KSPPS Berkah } \\
\text { Bersama }\end{array}$ & 6.386 .669 .798 & 375.845 .798 & 6.010 .824 .000 & - & 0,00000 & 0,00000 \\
\hline \multicolumn{2}{|c|}{ Total } & 364.349 .890 .965 & 156.279 .161 .759 & 92.415 .358 .775 & 6.282 .268 .539 & 0,01724 & 0,06798 \\
\hline \multicolumn{2}{|c|}{ Average } & $16.561 .358 .680,23$ & 7.103.598.261,77 & $4.200 .698 .126,14$ & $285.557 .660,86$ & 0,01724 & 0,06798 \\
\hline
\end{tabular}

From the financial data that has been processed, it is known that the total assets of the cooperatives are IDR $364,349,890,965$, with total debt amounting to IDR. $156,279,161,755$, while the total capital is IDR. $92,415,358,775$, with the remaining proceeds of IDR $6,282,268,539$, -

This shows that funds managed by cooperatives are very large and will have an impact on members' business turnover. The capital structure as a whole the comparison between total debt and assets shows a ratio of $42.89 \%$. This shows that $42 \%$ of funding and asset financing are financed by debt. This means that the remaining around $57.11 \%$ is financed by self-capital. This is quite good because it shows that financing with own capital is greater than financing from loans.

The ability of the cooperative as a whole to produce the remaining results of the business the ratio is $1.72 \%$, which means that from IDR 100 assets it can only produce return of IDR 1.72. This ratio is very small when compared to the ratio of return on investment (ROI) which must be achieved in the amount of more than 
$10 \%$. But in a cooperative the success is measured not only from the profits achieved but also from the benefits felt by the members. Benefits can be obtained with cooperative transactions with low prices, low costs, which are called direct benefits and indirect benefits in the form of sharing the amount of return to members on the basis of member transactions with cooperatives.

The average amount of asset value is IDR $16,561,358,680.23$. The average amount of debt is IDR 7,103,598,261.77.

The average amount of own capital is IDR 4,200,698,126.14 and the average return is IDR $285,557,660.86$.

\section{Conclusion}

Cooperative business is directly related to the improve the business and welfare of members, so that with good supervision will have a high beneficial impact for members. Findings Implementation of Good Corporate Governance encourages cooperative management in conducting savings and loan activities effectively and efficiently by taking into account the principles of cooperatives and prudential principles so that the cooperative assessment is transparent, accountable and responsive. Management of cooperatives can be done effectively and with the implementation of Good Corporate Gov

\section{Acknowledgements}

Author thanks to Rector and Vice Rector of Ikopin ; Dr.(HC)Burhanuddin Abdullah,.MA,Dr. Sugiyant.,MSc, Dandan Irawan.,MSc, Dr. Yuanita Indriani.,MSi and Director of Management Departmen, Dr. Giyanto Purbo.,MSc for their expert advise and encouragement throughout this research, Director of research institutions and community service Dr. Erry Supriyadi.,MSc for his extraordinary support in this research process. Cooperatives and Ministry of Cooperatives and Small and Medium Enterprises for data provided.
Thank you to my colleagues and my family for their wonderful collaboration, you supported me greatly and were always willing to help me, also to Tika Septiani, who help processing data and tidying up the writing of this paper. This research would have been impossible without the support from Ministry of Technology Research and Education. This study is one of stage for conducting cooperative business performance research in relation to the creation of value of firm and share holder equity, financed by Kemenristek Dikti Indonesia.

\section{References}

Abdallah, A. A. N., \& Ismail, A. K. (2017). Corporate governance practices, ownership structure, and corporate performance in the GCC countries. Journal of International Financial Markets, Institutions and Money. https://doi.org/10.1016/j.intfin.201 6.08 .004

Andriani Tisna, G., \& Agustami, S. (2016). Pengaruh Good Corporate Governance Dan Ukuran Perusahaan Terhadap Kinerja Keuangan Perusahaan (Pada Perusahaan Perbankan Yang Terdaftar Di Bursa Efek Indonesia (Bei) Tahun 2010-2014). Jurnal Riset Akuntansi Dan Keuangan, 4(2), 1035-1046. https://doi.org/10.17509/jrak.v4i2. 4038

Ardiyani Lestari, Good Cooperate Finance dan Kinerja Koperasi. Bandung, 2017

Asher, M. G. (2007). Reforming governance and regulation of urban cooperative banks in India. Journal of Financial Regulation and Compliance, 15(1), 20-29. https://doi.org/10.1108/135819807 10726769

Darmawati. Deni Khomsiyah., dan Rika Gelar Rahayu. (2005). Hubungan 
Corporate Governance dan Kinerja Perusahaan. Simposium Nasional Akuntansi VII, IAI, 2005 .

Dasuki, R. E. (2018a). KInerja Usaha Koperasi Melalui Pendekatan Tingkat Kesehatan Kaitannya Dengan Penciptaan Value of Firm, $1(1), 41-56$.

Dasuki, R. E. (2018b). Study \& Accounting Research. STAR Jurnal Akuntansi Dan Bisnis, XV(2), 4155. Retrieved from www.stiestembi.ac.id

Dewayanto, T. 2010. Pengaruh Mekanisme Good Corporate Governance terhadap Kinerja Perbankan Nasional (Studi Pada Perusahaan Perbankan Terdaftar di Bursa Efek Indonesia Periode 2006-2008). Jurnal Fokus Ekonomi, 5(2):h:104-123.

Fathi, Jouini. 2013. Corporate Governance and The Level of Financial Disclosure by Tunisian Firm. Journal of Business Studies Quarterly.

Group, E., \& Limited, P. (2004).

Towards good corporate governance: Realistic or idealistic? Strategic Direction, 20(9), 18-20. https://doi.org/10.1108/025805404 10556429

International Co-operative Alliance (ICA). 2002. Jati Diri Koperasi ICA Cooperative Identity Stantement Prinsip-prinsip Koperasi untuk Abad Ke-20. LSP2I.

Ippolito, A. (2009). Creating value in multiple cooperative relationships. International Journal of Quality and Service Sciences, 1(3), 255270.

https://doi.org/10.1108/175666909 11004195

Jouini, F. (2013). Corporate Governance and the Level of Financial Disclosure by Tunisian Firm. Journal of Business Studies Quarterly, 4(3), 95-111. Retrieved from

http://resolver.lrc.macewan.ca/mac ewan?url_ver=Z39.88-

2004\&rft_val_fmt=info:ofi/fmt:ke v:mtx:journal $\&$ genre $=$ article $\&$ sid $=$ ProQ:ProQ\%253Aabiglobal\&atitle $=$ Corporate + Governance + and + the + Level + of + Financial + Disclosure + by + Tunisian+Firm\&title $=$ Journal + of + Business + Stud

Kaihatu, T. (2006). Good Corporate Governance dan Penerapannya di Indonesia. Manajemen Dan Kewirausahaan. https://doi.org/10.9744/jmk.8.1.pp. $1-9$

KNKG (National Commite on Governance. 2006. Pedoman Good Corporate Governance Indonesia. Jakarta.

Kyazze, L. M., Nkote, I. N., \& Wakaisuka-Isingoma, J. (2017). Cooperative governance and social performance of cooperative societies. Cogent Business and Management. https://doi.org/10.1080/23311975.2 017.1284391

Lozano, M. B., Martínez, B., \& Pindado, J. (2016). Corporate governance, ownership and firm value: Drivers of ownership as a good corporate governance mechanism. International Business Review. https://doi.org/10.1016/j.ibusrev.20 16.04.005

Luh Gede Diah Ary Pradnyaswari dan I Gusti Ayu Made Asri Dwijaputri. 2016. Pengaruh Prinsip-prinsip Good Corporate Governance pada Kinerja Keuangan Koperasi di Kabupaten Klungkung. E-Jurnal Akuntansi Universitas Udayana.

Mas Daniri Achmad. 2005. Good Corporate Governance: Konsep dan Penerapannya dalam Konteks Indonesia. Jakarta: Ray Indonesia.

Peraturan Deputi Bidang Pengawasan Kementrian Koperasi dan UMKM Republik Indonesia Nomor 07 Tahun 2016. 
Peraturan Pemerintah Koperasi dan UMKM No.17 Tahun 2015 Tentang Pengawasan Koperasi.

Pradnyaswari, L. G. D. A., \& Putri, I. G. A. M. A. D. (2016). pengaruh Prinsip-Prinsip Good Corporate Governance pada Kinerja Keuangan Koperasi di Kabupaten Klungkung. E-Jurnal Akuntansi Universitas Udayana, 14(2), 10641091.

https://doi.org/10.1016/j.cub.2006. 05.054

Prijambodo, 2012. Tata Kelola yang Baik pada Koperasi (Good Governance Cooperative) Satu Kebutuhan Peningkatan Kualitas SDM Koperasi.

Rima Elya Dasuki,Integrasi Kinerja Sosial dan Kinerja Keuangan Koperasi,Bandung 2014

RoshaneZaigham,NadiaAsghar,Sustaina bility of Micro Finance Banks : A Comparative Case Studi from Pakistan,Interdiciplinary Journal of Contemporary Reasearch in Business, Vol 3 No 8,Dec 2012

Siboro, D. T. 2007. Hubungan Good Corporate Governance (GCG) dengan Pengungkapan Laporan Keuangan. Jurnal Fokus Ekonomi, 2(2):h:17, 29.

Surroca, J., García-Cestona, M. A., \& Santamaria, L. (2006). Corporate Governance and the Mondragón Cooperatives. Management Research: Journal of the Iberoamerican Academy of Management, 4(2), 99-112. https://doi.org/10.2753/JMR15365433040202

Totok Dewayanto. (2010). Pengaruh Mekanisme Good Corporate Governance terhadap Kinerja Perbankan Nasional. Studi pada Perusahaan Perbankan yang Terdaftar di Bursa Efek Indonesia Periode 2006-2008. Fokus Ekonomi, 5(2), 104-123. https://doi.org/10.1109/VETECS.2
009.5073451

\section{Biographies}

\section{Rima Elya Dasuki}

Undergraduate (S1) from Faculty of Economics Padjadjaran University (UNPAD) Bandung Indonesia (major in Financial Mangement)-1986, Master degree: University of Ghent Belgium,Agriculture Economic (major in Financial Management)-1990, Doctoral degree: Management Science Doctor (major in Financial Management),Padjadjaran University (UNPAD) Bandung-Indonesia-2014

Working as lecture and researcher at Lembaga Layanan Dikti 4 (Institut Manajemen Koperasi Indonesia / Indonesian Cooperative Management Institute)-West Java-Indonesia.

Publication and research related to management, financial management, Cooperative, publication at international and national journal. (i.e: European journal of business and economic studies, International Journal of Applied Business and Economic Research, Risk Governance \& Control: Financial Markets \& Institutions, Indonesian Journal of Economics and Business).

Member of Indonesian Economy Graduate (ISEI / Ikatan Sarjana Ekonomi Indonesia), Indonesian Management Forum (FMI/Forum Manajemen Indonesia)

\section{Ardiyani Lestari}

Undergraduate (S1) from Institut Manajemen Koperasi Indonesia (Indonesian Cooperative Management Institute)-2016, Working at Bank Mandiri 